\title{
The results of grapevine breeding in the Republic of Moldova - in context of climatic and socio-economic challenges
}

\author{
G. Savin, V. Cornea, and I. Baca \\ Research and Practical Institute for Horticulture and Food Technologies, 59, Vieru str., MD-2070, Chisinau, Republic of Moldova
}

\begin{abstract}
The results achieved in Republic of Moldova in using the potential of grapevine Gene pool over the past 40 years are significant: new varieties for diverse utilisation, designed for complex biological resistance to stress factors, for reduced pressing on the environment and for excellent capabilities for ecological agriculture. Breeding programs resulted in modernization of assortment - were created more than 80 new varieties for table and wine grapes, most of them with advanced biological resistance, and 32 varieties were included in actual assortment and other are in the process of testing. An important feature of this assortment is presence of seedless varieties, well adapted to our geographical area. According to their characteristics (resistance, quality, productivity), created seedless varieties are not only a pioneering for the assortment of the Republic of Moldova, but for the entire Euro-Asian region. New seedless varieties and perspective elites manifest an increased percentage of buds started in vegetation after the wintering. High fertility, medium to large and very large grapes, accumulation of sugars and total acidity in must favourably for consumption of fresh grapes or for technological processing, suitability for long-term storage and transportability for some of them, denote their high productive and qualitative potential.
\end{abstract}

\section{Introduction}

In the Republic of Moldova viticulture is a branch with major economic and social impact. According to O.I.V. Statistical Report [1], the republic holds the 14th place in the world after the area of the vineyards (about 140 thous. ha.), the 19th position after the volume of produced wines (estimated at 2.0 million hl) and the 12th position after the volume of exported wines ( 1.4 million $\mathrm{hl})$. An important component of the viticulture sector of the republic is the production of table grapes [2]: 91 thousand tons of grapes, out of which over $50 \%$ are destined for export (50 thousand $\mathrm{t}$ ).

The country's pedoclimatic conditions are generally favourable for viticulture, but the particularities of the territory and of the climate impose certain risks: the territory of the republic is located at the northern limit of the industrial viticulture, for which the limiting factors are the wintering conditions, the early frosts in the autumn and the late frosts in the spring [3].

The winter season is short (80-105 days) and relatively warm, but in some winters temperatures can drop to $-34 \ldots-36^{\circ} \mathrm{C}$. At the same time winter climatic conditions are very unstable: during the seson can ocur up to 9 thaws, sometimes with suddenly fluctuations of temperatures within 24 hours from negative to positive values. These thaws are characterized by relatively high temperatures, and since its duration can be up to 45-60 days, they can cause the onset of vegetation (activates biological processes).

First autumn frosts (occur in mid-October, but may also take place in the second or third decades of September) can cause grapevine production losses of $20-70 \%$, but also reduce grape production in the next year by $30-40 \%$. Late spring frosts (posiible at May 21-22) can completely compromise the harvest.

In summer the air temperature can rise up to $+38 \ldots+41{ }^{\circ} \mathrm{C}$. The annual precipitation amount is $370-560 \mathrm{~mm}$, but it is characterized by an increased variability over the years $( \pm 200-300 \mathrm{~mm}$ per year).

The relief of $80 \%$ of the territory of the republic is rugged and therefore under the action of the relief elements the modification (amplification or diminution) of all agroclimatic factors takes place [4].

The expression of these peculiarities is accentuated, aggravated by the phenomenon of climate change (CC), which has become increasingly common during the last decades. Analysis of annual averages values of main meteorological parameters [5] indicates an increasing, over the last decade, of multiannual climate average of air temperatures; was achieved the record of maximum temperature in the history of instrumental observations in R.Moldova $\left(+41.5^{\circ} \mathrm{C}\right.$ and $\left.+42.4{ }^{\circ} \mathrm{C}\right)$; also are noted the increased intensity (duration 3-15 times higher than the norm) of manifestation of extreme weather (very high temperatures, droughts). The analysis of evolution of climatic parameters in Moldova for longer periods of time confirms the general trend in their changing [6]: during the last 30-40 years an increase in average air temperature estimated at $+1.41^{\circ} \mathrm{C}$, the sum of active temperature rose from $+3790{ }^{\circ} \mathrm{C}$ to $+3810^{\circ} \mathrm{C}$. The direct impact on viticulture of these changes is manifested in some cases by the decrease in grape production (loss values vary between $2.4 \%$ and $46.1 \%)$.

The consequences of $\mathrm{CC}$, at global and local level, are multiple and complex. The results of a study of the impacts of climate change on the economy of Washington State [7] had highlighted different aspects of this 
phenomenon: the climatic, direct economic, social, biological and agricultural. The economic impact seems to be more pronounced because of the frequent manifestation of extreme events and the cumulative effect will increase due to the interaction between the various sectors of industry and economy. Was revealed a mixed impact of climate change on viticulture: some traditional areas of some varieties will be abandoned due to exceeding temperature tolerance limits, other, colder will be populated.

Synthesis of the literature sources concerning the impact of $\mathrm{CC}$ on the vitiviniculture sector $[8,9]$ established the variety, diversity and complexity of topics. The assessment of the dynamics of the main climatic factors during the last century and forecasts for the future years and a longer period of time [10-13] denote the trend of increasing the average air temperatures, the danger of droughts in some regions, virulence of pathogens and pests. It was found that the data of the phenological phases shift with 10-20 days compared to the middle of the 20th century $[10,11,14-16]$ and, in connection with this, the change in the characteristics of the obtained production the increase of the alcoholic level, the decrease of acidity at harvesting, the change of the aromatic and polyphenolic profile, the decrease of the yield.

Various solutions are proposed for monitoring and mitigating the consequences of $\mathrm{CC}$ : the creation of a measurement network and a web platform (the ADVICLIM Project) [15], the development of strategies and adaptation methodology [11]; the use of potential of the European Climate Assessment Tool (ECA \& D) to monitor climate change is examined [17].

Aware of the importance of the proposed measures, we focus on a complex issue - improving and adapting the assortment to $\mathrm{CC}$ and their consequences.

Global climate change creates new challenges for plants, including new complex combinations of environmental conditions to which plants need to adapt [10]. To a certain extent, local varieties are an indirect manifestation of regional climatic conditions, their evolution over the years. Is attested an increased potential for adaptability to the climatic stresses of the old native varieties [18].

According to some estimations [19] the Chardonnay variety, ranked 5th in the world by occupied area, is cultivated and the quality production is obtained in various wine-growing regions, instil the optimism of maintaining the same potential for adaptation under the climatic challenges. Changing the areas available for Chardonnay cultivation is already visible in the last 50 years - the restriction of some favorable areas and the appearance of other new areas [17].

In the context of the CC phenomenon OIV [20] provides some recommendations, inclusiv on the adaptation of plant material (varietal or clonal adaptation, rootstock), of vitivinicultural techniques to new challenges. Grapevine breeding continue to be of a major importance in progress of vitiviniculture [21-23]. The breeder's task is to broaden the genetic basis in such a way as to increase the degree of adaptability to climatic and socio-economic challenges.

In the Republic of Moldova the grapevine breeding programs were oriented to create the new varieties with complex resistance to unfavorable factor of environment (low temperatures, frosts, pathogens) and well adapted to the specificity of local conditions. This activity began

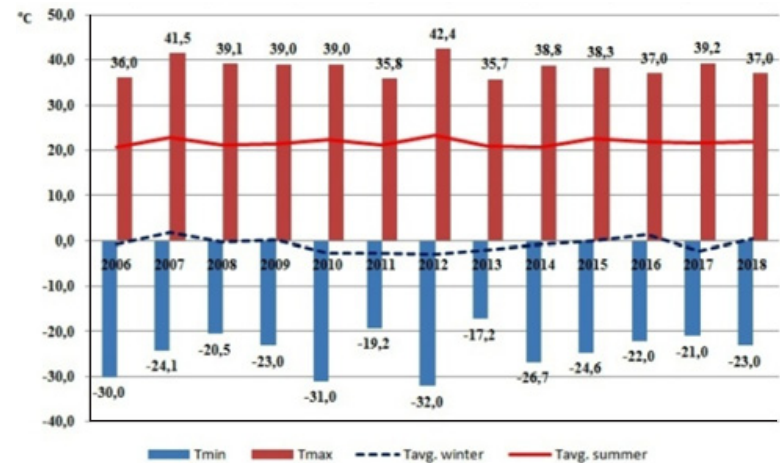

Figure 1. Extreme temperatures during the summer and winter seasons for the period of study.

in the $60 \mathrm{~s}$ of the past century and in the result of evaluation of $F_{1}$ populations some theoretical conclusions were made $[24,25]$ : the values of coefficients of linear correlation between berries quality of seedlings and resistance to winter hardiness, between the resistance to winter hardiness and resistance to mildew are small and insignificant, which suggests that descendants have inherited these traits independently. This shows absence of linkage between genes or gene complex that causes the studied characters or linkage is not manifested. Therefore, there are not the genetic barriers for heredity of quality and resistance, for combination in a single genotype of resistance to mildew and frost with high quality of berries.

Practical confirmation of this hypothesis results in the creation of more than 80 new grapevine varieties of varied use, most of them with increased biological resistance [22]. After the testing in the frame of State Commission for Crops Testing 32 new varieties were admitted for industrial cultivation [26]. Due to the increased quality and relative or advanced resistance to winter conditions and pathogens the varieties Moldova, Codreanca (well known under synonym Black magic), Yubilei Zhuravelya, Pamiati Negrulea and other becoming the components of the standard assortment, also appreciated in other countries.

A significant result of this activity is the creation and completion of the grapevine assortment, for the first time in the Republic of Moldova, with seedless varieties for diverse use and improved resistance to unfavorable factors. In the paper are presented new seedless varieties admited for industrial use, as well as new perspective elites, resulted from the breeding program.

\section{Materials and methods}

The observations were made during the period of 2006-2018 years within the experimental plots of the Institute's Grapevine Genetic Pool. The general climatic characteristic of plots (located in the south of Chisinau city, $46^{\circ} 58^{\prime} 39.65^{\prime \prime} \mathrm{N}$ and $28^{\circ} 46^{\prime} 21.68^{\prime \prime} \mathrm{E}$, altitude $201 \mathrm{~m}$ ) represents the average values of weather parameters for the republic. Years of observation includes varied weather conditions, especially with regard to extreme temperatures during the summer and severe winter temperatures (Fig. 1), rainfall deficit or severe droughts [5].

In study were included new seedless varieties, created in the Republic of Moldova, approved for industrial cultivation [26], as well as new perspective elites (Table 1, Fig. 2). The planting scheme is $3.0 \times 1.25 \mathrm{~m}$, training 
Table 1. New seedless genotypes and perspective elites included in study.

\begin{tabular}{|c|c|c|c|c|}
\hline Genotype name & $\begin{array}{c}\text { Variety } \\
\text { number } \\
\text { VIVC [28] }\end{array}$ & $\begin{array}{l}\text { Color of } \\
\text { berry skin }\end{array}$ & Direction of use & $\begin{array}{c}\text { Time of } \\
\text { physiological stage } \\
\text { of full maturity } \\
\text { of the berry }\end{array}$ \\
\hline \multicolumn{5}{|c|}{ Varieties included in standard assortment (admited for industrial use) } \\
\hline Apiren roz & 23106 & rose & table grape, industrial processing & early-medium \\
\hline Apiren alb & 23099 & green-yellow & table grape, wine grape, industrial processing & early-medium \\
\hline Apiren Basarabean & 24934 & rose & table grape, wine grape, industrial processing & early-medium \\
\hline Apiren roz timpuriu & 24933 & rose & table grape, industrial processing & very early \\
\hline Apiren negru de Groze?ti & 23105 & blue-black & industrial processing & medium \\
\hline \multicolumn{5}{|c|}{ Perspective seedless elites } \\
\hline $\mathrm{I}-15-15$ & - & green-yellow & table grape, wine grape, industrial processing & late \\
\hline I-5-68 & - & blue-black & industrial processing & late \\
\hline $\mathrm{II}_{2}-1-97$ & - & green-yellow & table grape, wine grape, industrial processing & medium-late \\
\hline $\mathrm{II}_{2}-13-66$ & - & rose & wine grape, industrial processing & late \\
\hline \multicolumn{5}{|l|}{ Perspective seedy elites } \\
\hline Basarabia & - & blue-black & table grape & late \\
\hline $\mathrm{I}-5-58$ & - & rose & table grape & very late \\
\hline Gen Piticul & - & green-yellow & table grape & very late \\
\hline $\mathrm{I}-2-24$ & - & blue-black & wine grape & medium-late \\
\hline
\end{tabular}

system is the double cordon on the high trunk $(60 \mathrm{~cm})$. The fertility and productive parameters: the number of buds started in vegetation after wintering, total number of shoots and number of fertile shoots, number of bunches, weight and dimensions of bunch and berry were determined. The ampelographic description was performed according to the OIV Descriptor List [27].

The processing of the experimental data, the graphical presentation was done with the MO EXCEL 2007 and STATISTICA 7.0 software package.

\section{Results and discussions}

Established absence of genetic barriers for heredity of high quality of berries and improved resistance, the success of the initial breeding programs, as well as new requirements of consumers and market, have inspired for creation of seedless varieties with multiple resistance, absent in our traditional grapevine assortment.

In the republic were created and homologated seedless varieties Kişmiş lucistâi (well known under synonym Supernova) and Kişmiş Moldovenesc (author M. Juraveli) with standard quality, but sensitive to frost and fungal diseases. In order to create a seedless varieties better adapted to local conditions, as initial material were used existing genetic resources: traditional sensible seedless varieties, hybrid forms and varieties of $\mathrm{M}$. Juravel, created in previous researches, genotypes from the Ampelographic Collection, hybrids obtained with the participation of Seyve Villards, main purpose was to create the initial population for selection of seedless forms resistant to wintering and mildew. First pollinations were made in 1970, in 1971 was founded the nursery of descendants and in 1972 - the field of hybrids.

In the studied biological material high quality of berries, resistance to mildew and frost were found in various combinations [22]. We note, in this case, the presence of a qualitatively new character compared to previous breeding program - seedlessness. Therefore, the above hypothesis was confirmed, and developed on a biological material with more complex characteristics: quality, including seedlessness, productivity, early maturity, various directions of use, resistance to unfavourable abiotic and biotic factors.

By 1980 were highlighted the first elites. As a result of the studies, were revealed and homologated five new varieties - Apiren roz (Rose seedless), Apiren alb (White seedless), Apiren Basarabean (Seedless from Basarabia), Apiren roz timpuriu (Early rose seedless) and Apiren negru de Grozeşti (Black seedless from Grozesti) [22,26]. All these varieties are patented.

Variety Apiren roz is characterized (Tables 2-3) by a medium vigour, medium-large bunches of cylindricalconical shape, medium compact; the berry is round or slightly elliptic, medium, rose - rose-violet, crispy, with a fine flavour. The grapes have a good transportability, can be kept for a long time.

The Apiren alb variety has a relatively high vigour, bunches are large or very large, conical, berries normally arranged on bunches; berries are elliptic, small-medium, yellow-green, with a slightly firm flesh, neutral flavor. Fresh wines, made from Apiren alb have a light floral bouquet.

Apiren Basarabean ia characterized by mediumhigh vigour, medium-sized, conical-shaped bunches with normally arranged berries on the bunches; the berry is short elliptic, medium, with rose color of skin, neutral flavor.

The interval of full maturation of varieties Apiren roz, Apiren alb and Apiren Basarabean, in the conditions of the Central region of the Republic of Moldova, ranges between August 25 and September 15. 


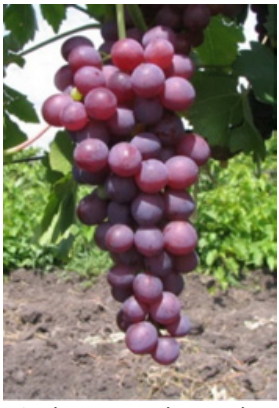

Apiren roz timpuriu

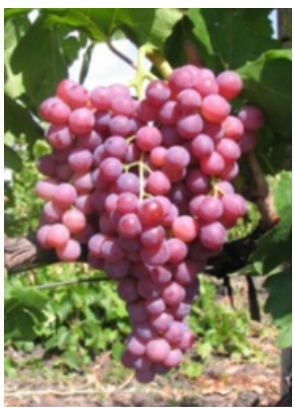

Apiren roz

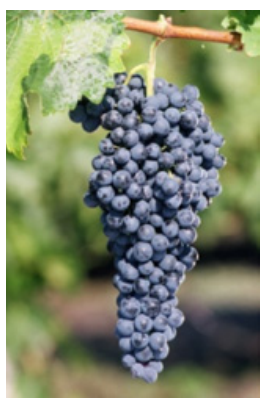

Apiren negru de Grozesti

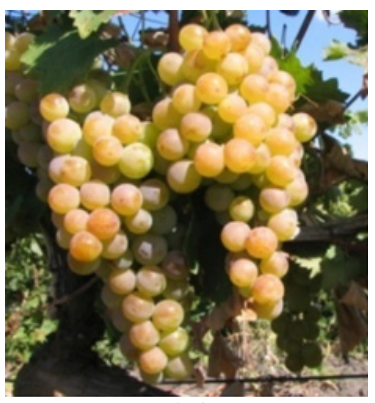

$\mathrm{II}_{2}-1-97$

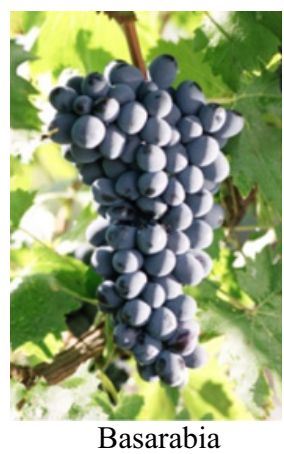

Figure 2. Seedless varieties admitted to use in industrial plantations in Republic of Moldova and perspective elites.

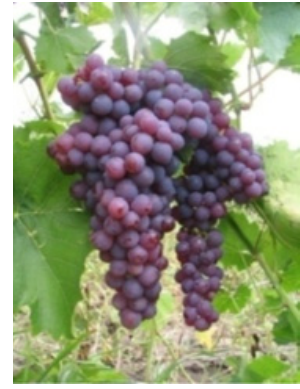

August, 30

$z=183 \mathrm{~g} / \mathrm{l}$

t.a. $=9,15 \mathrm{~g} / \mathrm{l}$
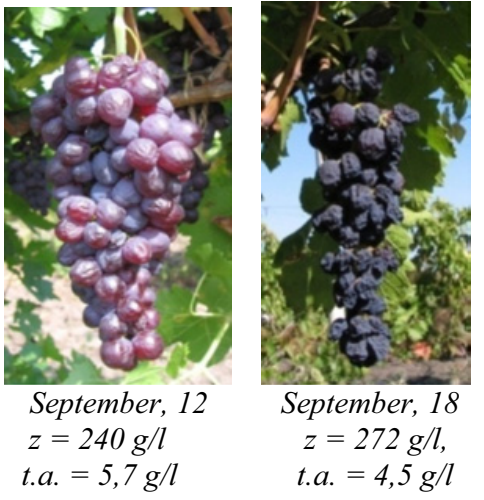

Figure 3. Evolution of grapes of the variety Apiren roz timpuriu on maturation on the bush ( $\mathrm{z}$ - sugar content, t.a. - tartaric acidity).

Variety Apiren roz timpuriu, with the period of maturation ranging from 25 July to 15 August, belongs to the group of early maturing varieties. It is characterized by medium vigour, small-medium, conical-shaped bunches, with round or short elliptic, crispy berries, with rose - roseviolet colour of skin. The content of the must in sugar at the consumption maturation is $180-240 \mathrm{~g} / \mathrm{l}$, but when the grapes are stored on the bushes, the dehydration process takes place (Fig. 3) and the berries can accumulate up to $280 \mathrm{~g} / \mathrm{l}$ of sugars. Comparative to other varieties with the same maturation period, grapes of Apiren roz timpuriu are not affected by diseases and insects, keep the commercial aspect for a longer time.

The Apiren negru de Grozesti variety is characterized by high growth vigour, medium, conical shaped bunches, with medium compact round, small-medium, black-blue, juicy berries with neutral flavour. The period of full maturation is between August 25 and September 15.

The resistance of these varieties to the main limiting factor - the severe wintering temperatures, was estimated based on the percentage of buds started in the vegetation after wintering (Fig. 4, a). Increased average values for this index and a relative narrow $95 \%$ confidence interval denote a stable behaviour of varieties throughout the study period. Varieties Apiren roz timpuriu, Apiren Basarabean and Apiren negru de Grozesti possess a high percentage $(>60 \%)$ of fertile shoots (Fig. 4, b), some of which have 2 inflorescences. Advanced wintering resistance, the increased potential of these varieties to produce fertile shoots from the angled and dormant buds, greatly reduce the risk of plant damages by low temperatures and the possibility of restoration of plant's architectonics in case of damage.

Observations over the years suggest the possibility for reduction in half, for these varieties, of the number of chemical treatments for disease and pest control compared to $V$. vinifera susceptible varieties. This effect increases in years favorable for viticulture, when only 1-2 treatments can be applied to these varieties.

New seedless varieties were also studied to investigate the possibilities of their use in the food industry [29]. According to the dry matter content, all varieties meet the requirements for industrial processing. On the organoleptic evaluation of the products the highest was appreciated the 
Table 2. Indices of productivity and quality of new seedless varieties and perspective elites.

\begin{tabular}{|l|c|c|c|c|c|c|}
\hline Genotype name & $\begin{array}{c}\text { Bunch length/ } \\
\text { weight, g }\end{array}$ & $\begin{array}{c}\text { Bunch } \\
\text { width, } \mathbf{~ m m}\end{array}$ & $\begin{array}{c}\text { Berry length/ } \\
\text { weight, g }\end{array}$ & $\begin{array}{c}\text { Berry } \\
\text { width, mm }\end{array}$ & $\begin{array}{c}\text { Sugar content } \\
\text { of must, g/l }\end{array}$ & $\begin{array}{c}\text { Total acidity } \\
\text { of must, g/l }\end{array}$ \\
\hline \multicolumn{7}{|c|}{ Varieties included in standard assortment (admited for industrial use) } \\
\hline Apiren roz & $390.4 \pm 59.0$ & $174 / 123$ & $2.9 \pm 0.2$ & $19 / 18$ & 207 & 7.52 \\
\hline Apiren alb & $316.1 \pm 37.2$ & $226 / 130$ & $1.8 \pm 0.2$ & $15 / 13$ & 214 & 7.21 \\
\hline Apiren Basarabean & $274.9 \pm 16.8$ & $197 / 123$ & $1.5 \pm 0.1$ & $16 / 15$ & 202 & 7.10 \\
\hline Apiren roz timpuriu & $154.4 \pm 17.1$ & $154 / 84$ & $1.5 \pm 0.1$ & $16 / 15$ & 232 & 6.77 \\
\hline Apiren negru de Grozeşti & $221.0 \pm 30.0$ & $174 / 95$ & $1.6 \pm 0.1$ & $13 / 12$ & 200 & 7.37 \\
\hline \multicolumn{7}{|c|}{ Perspective seedless elites } \\
\hline I-15-15 & $237.8 \pm 28.9$ & $237 / 125$ & $1.8 \pm 0.1$ & $16 / 15$ & 182 & 5.31 \\
\hline I-5-68 & $306.8 \pm 34.0$ & $251 / 146$ & $1.2 \pm 0.1$ & $13 / 13$ & 210 & 6.33 \\
\hline II 2 -1-97 & $433.4 \pm 48.8$ & $174 / 133$ & $3.0 \pm 0.1$ & $18 / 17$ & 180 & 7.93 \\
\hline II ${ }_{2}$-13-66 & $350.0 \pm 41.1$ & $168 / 130$ & $1.8 \pm 013$ & $16 / 14$ & 197 & 7.11 \\
\hline \multicolumn{7}{|c|}{ Perspective seedy elites } \\
\hline Basarabia & $351.5 \pm 50.1$ & $182 / 121$ & $4.5 \pm 0.3$ & $25 / 20$ & 200 & 7.42 \\
\hline I-5-58 & $750.6 \pm 75.1$ & $193 / 154$ & $7.8 \pm 0.4$ & $27 / 23$ & 178 & 6.79 \\
\hline Gen Piticul & $203.1 \pm 15.0$ & $155 / 99$ & $4.6 \pm 0.3$ & $24 / 19$ & 187 & 8.61 \\
\hline I-2-24 & $144.0 \pm 14.8$ & $119 / 88$ & $1.4 \pm 0.1$ & $13 / 15$ & 203 & 7.44 \\
\hline
\end{tabular}

a)
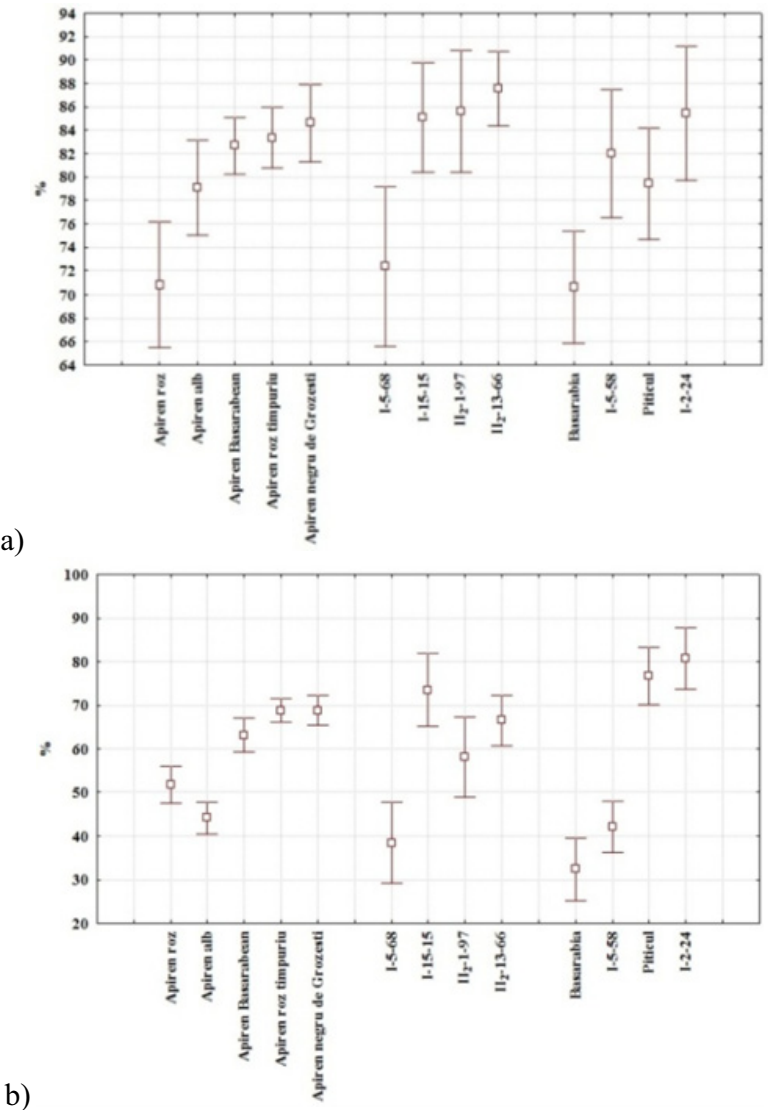

Figure 4. Percent of buds started in vegetation (a) and percent of fertile shoots (b) ( $\square-$ mean value; I-95\% confidence interval).

jams: Apiren alb - 4.5; Apiren roz - 4.8; Apiren negru de Grozesti - 4.9 (on the scale up to 5 points). The raisins prepared from the Apiren alb and Apiren roz timpuriu were appreciated with the note 4.6 , the last variety, according to the organoleptic qualities, being similar to the raisins produced from the Middle Asia varieties.

The perspective varieties and elites included in the study posed a wide variety of characters and useful properties necessary for completing the assortment and including in future prebreeding and breeding programs (Tables 2-3).

The length of bunches varies from small and medium sized in group of seedy genotypes to large and very large in grup of seedless elites (I-15-15, I-5-68). According the weight of bunches we remarc elite I-5-58 with very large grapes and berries. All perspective elites provide a medium to high accumulation of sugars and lowmedium accumulation of total acidity in must favorably for consumption of fresh grapes or for technological processing.

All perspective elites posed a good resistance to winter conditions - the percent of buds started in vegetation ranges from $72.4 \%$ (I-5-68) to $87.6 \%$ (II2-1366) for seedless genotypes and from $70.6 \%$ (Basarabia) to $85.5 \%$ (I-2-24) for seedy genotypes. A more pronounced variability of percent of fertile shoots is revealed: from $39.8 \%$ (I-5-68) to $73.5 \%$ (I-15-15) for seedless elites and from $32.4 \%$ (Basarabia) to $80.7 \%$ (I-2-24) in group of elites with seeds. In this group are manifested by the increased percentage of shoots with 2 inflorescences the genotypes Gen Piticul (44\%) and I-2-24 (62\%).

Diversity of time of physiological stage of full maturity of the berry of presented genotypes allows to include it in varietal as well as geographical conveyor of grapes. Also, these varieties create the premises of a new directions in food industry: consumption of fresh grapes, long term storage, producing of raisins, jams, marinades, juice, etc., creating new jobs. Presented varieties and elites can be used in projecting and the foundation of industrial plantations by alternation of varieties with different levels of resistance, which will serve as natural 
Table 3. Diversity of characters of new seedless varieties and perspective elites.

\begin{tabular}{|c|c|c|c|c|c|c|c|c|c|c|c|c|c|}
\hline \multirow[b]{2}{*}{ Genotype name } & \multicolumn{4}{|c|}{ Bunch } & \multicolumn{8}{|c|}{ Berry } & \multirow[b]{2}{*}{ OIV 304} \\
\hline & $\begin{array}{l}\text { OIV } \\
202\end{array}$ & $\begin{array}{l}\text { OIV } \\
203\end{array}$ & $\begin{array}{l}\text { OIV } \\
208\end{array}$ & $\begin{array}{c}\text { OIV } \\
502\end{array}$ & $\begin{array}{l}\text { OIV } \\
220\end{array}$ & $\begin{array}{l}\text { OIV } \\
221\end{array}$ & $\begin{array}{c}\text { OIV } \\
223\end{array}$ & $\begin{array}{l}\text { OIV } \\
225\end{array}$ & \begin{tabular}{|l|} 
OIV \\
236
\end{tabular} & $\begin{array}{c}\text { OIV } \\
503\end{array}$ & $\begin{array}{c}\text { OIV } \\
505\end{array}$ & $\begin{array}{c}\text { OIV } \\
506\end{array}$ & \\
\hline \multicolumn{14}{|c|}{ Varieties included in standard assortment (admited for industrial use) } \\
\hline Apiren roz & 5 & 5 & 3 & 5 & 5 & 5 & $2 \mid 3$ & 2 & 3 & 3 & 7 & $3-5$ & $3-5$ \\
\hline Apiren alb & 9 & 5 & 2 & 3 & 5 & 3 & 3 & 1 & 2 & 1 & 7 & $3-5$ & $3-5$ \\
\hline Apiren Basarabean & 7 & 5 & 2 & 3 & 5 & 5 & 3 & 2 & 1 & 1 & 7 & $3-5$ & $3-5$ \\
\hline Apiren roz timpuriu & 5 & 3 & 2 & 1 & 5 & 5 & $2 \mid 3$ & 2 & 3 & 1 & 9 & $2-3$ & 1 \\
\hline Apiren negru de Grozeşti & 5 & 3 & 2 & 3 & 3 & 3 & 2 & 6 & 1 & 1 & 7 & $3-5$ & $3-5$ \\
\hline \multicolumn{14}{|c|}{ Perspective seedless elites } \\
\hline $\mathrm{I}-15-15$ & 9 & 5 & 1 & 3 & $3-5$ & $3-5$ & 2 & 1 & 1 & $1-3$ & 5 & $1-3$ & 7 \\
\hline $\mathrm{I}-5-68$ & 9 & $5-7$ & 1 & 3 & 3 & 3 & 2 & 6 & 1 & 1 & 7 & 3 & $5-7$ \\
\hline $\mathrm{II}_{2}-1-97$ & 5 & 5 & 3 & $3-5$ & 5 & 5 & 2 & 1 & 2 & 3 & 5 & 5 & 5 \\
\hline $\mathrm{II}_{2}-13-66$ & 5 & 5 & 3 & $3-5$ & 5 & 3 & 3 & 2 & 1 & $1-3$ & $5-7$ & $3-5$ & 7 \\
\hline \multicolumn{14}{|c|}{ Perspective seedy elites } \\
\hline Basarabia & $5-7$ & 5 & 2 & $3-5$ & $7-9$ & 5 & 6 & 6 & 1 & 5 & $5-7$ & $3-5$ & $5-7$ \\
\hline $\mathrm{I}-5-58$ & 7 & 7 & 2 & 7 & 9 & 7 & 6 & $2 \mid 5$ & 1 & 7 & 5 & $3-5$ & $7-9$ \\
\hline Gen Piticul & 5 & $3-5$ & 1 & $1-3$ & 7 & 5 & 3 & 1 & 1 & 5 & 5 & $3-5$ & 7 \\
\hline $\mathrm{I}-2-24$ & 3 & 3 & 1 & 1 & 3 & 3 & 2 & 6 & 1 & 1 & 7 & $3-5$ & $5-7$ \\
\hline
\end{tabular}

barriers to pathogens, a "safety ecological belt", enabling ambient friendly technologies: fewer chemical treatments, minimum technological pressing, directed toward organic production.

In condition of multiple climate and social challenges is actualy the problem of reinforcing the segment of resistance to abiotic and biotic unfavorable factors, i.e. the development of a new generation of genotypes adapted to climate change through circadian system and metabolic pathway knowledge involvement, devoted for specific areal of each zone, in our case for the CarpathianDanubian-Pontic areal. The task of accumulation and conservation of grapevine genetic resources, creation of "critical mass" of necessary traits: quality / productivity, resistance to abiotic and biotic unfavorable factors of environment, adaptability etc. becomes strategic and above presented genotipes can serve as a components in achieving these goals based on accumulated latest molecular data and techniques in grapevine progress.

\section{Conclusions}

New seedless varieties with increased resistance to the unfavorable environmental factors have been created, patented and homologated and represent the basis for the modernization of the assortment, the diversification of the products obtained from the grapes, reducing pressures on fauna, flora, human genome, a necessary components for an ecological system.

The presence, at new seedless varieties and perspective elites, separately or in various combinations of a diversity of important agrobilogical traits: high quality, including seedlessness, productivity, resistance, other useful features, presents a criterion for theirs inclusion in the pre-breeding germplasm fund for further use in the improvement of the grapevine assortment.

The authors are grateful to the USAID "High Value Agriculture Activity in Moldova (HVAA)" Project for the financial support for participation to $42^{\text {nd }}$ OIV Congress.

\section{References}

[1] OIV Statistical Report on World Vitiviniculture (OIV, 2018)

[2] Table and Dried Grapes (FAO and OIV, 2016)

[3] G.F. Lasse, Klimat Moldavskoy SSR (Leningrad: Gidrometeoizdat, 1978) (in Russian)

[4] Z.A. Mishchenko Uchet mikroklimata pri razmeshchenii vinogradnikov $i$ sadov (Kisginev, Shtiintsa, 1986) (in Russian)

[5] Serviciul Hidrometeorologic de Stat, www . meteo.md

[6] M.D. Vronskih, Izmenenie klimata i riski seliskohozeaistvennogo proizvodtstva Moldovy (Grafema Libris, Kisinev, 2011) (in Russian)

[7] Impacts of Climate Change on Washington's Economy - A Preliminary Assessment of Risks and Opportunities, Web - available: https:// fortress.wa.gov/ecy/publications/ publications/0701010.pdf (2006)

[8] S. Sacchelli, S. Fabbrizzi, S. Menghini, Wine Econ. Policy, 5, 114 (2016)

[9] M.R. Mozell, L. Thach, Wine Econ. Policy, 3, 81 (2014)

[10] M. Boselli, G. Tempesta, M. Brandi, Bio Web Conf. 7, 01012 (2016)

[11] P. Aigrain, F. Brugière, E. Duchêne, I. Carcia de Cortazar-Atauri, J. Gautier, E. Giraud-Héraud, 
H. Hannin, N. Ollat, J.-M. Touzard, Bio Web Conf. 7, 03015 (2016)

[12] L. Irimia, C. Patriche, B. Roşca, V.V. Cotea, Bio Web Conf. 9, 01026 (2017)

[13] D. Santillan, V. Sotes, A. Iglesias, L.Garrote. Bio Web Conf. 12, 01001 (2019)

[14] G.V. Jones, M.A. White, O.W. Cooper, K. Storchmann, Climate Change 73, 319 (2005)

[15] J. Rochard, Bio Web Conf. 7, 01010 (2016)

[16] A. Donici, V. Enache, C. Simion, Aspects concerning climatic changes influence on vine vegetative phenological phase in "Dealu Bujorului" vineyard, Lucrări ştiinţifice UASMV „Ion Ionescu de la Brad” Iaşi, Seria Horticultură, 50, 427 (2007)

[17] C. Photiadou, N. Fontes, A. Rocha Graca, G. van der Schrier, Bio Web Conf. 9, 01002 (2017)

[18] L. Rotaru, C. Colibaba, The influence of climatic changes on the behavior of some grape varieties for white wines in moldavian vineyards, Lucrări ştiinţifice UASMV „Ion Ionescu de la Brad” Iaşi, Seria agronomie, 54, 174 (2011)

[19] C. Gavrilescu, B. Bois, Bio Web Conf. 7, 01013 (2016)

[20] OIV guidelines for studying climate variability on viticulture in the context of climate change, and its evolution, Web - available: http://www.oiv. int/oiv/info/enresolution (2015)

[21] L. Audeguin, C. Sereno, O. Yobrégat, Variéte de vigne de demain : évolutons attendues, attentes professionnelles et socétales, challengess, 38th World
Congress of Vine and Wine, 05002 (2015). DOI: 10.1051/oivconf/201505002

[22] Gh. Savin, Ameliorarea sortimentului viticol al Republicii Moldova (Ch. : S.n., Tipogr. AŞM, 2012)

[23] Gh. Savin, V. Cornea, Mobilization and exploration of genetic resources in development of sustainable viticulture in context of restrictive factors, Lucrări ştiinţifice, USAMV „Ion Ionescu de la Brad” Iaşi, Seria Horticultură 58, 151 (2015)

[24] G.A. Savin, Nasledovanie morozoustoicivosti $i$ mildiuustoicivosti $v F_{1}$ ot skreşcivania sortov $V$. vinifera L. so slojnâmi mejvidovâmi ghibridami: avtoref. diss. na soisk. uc. stepeni kand. s./h. nauk (K., 1970) (in Russian)

[25] M.S. Juraveli, G.A. Savin, Vzaimosviazi morozoustoicivosti, mildiu - ustoicivosti i kacestva vinograda, Sadovodstvo, vinogradarstvo i vinodelie Moldavii 12, 16 (1972) (in Russian)

[26] Catalog of Plant varieties for year 2019 (Chisinau, 2019)

[27] OIV Descriptor List for Grapevine Varieties and Vitis species, 2ed edn., Office International de la Vigne et du Vin (Paris, 2009)

[28] VIVC 2019, Vitis International Variety Catalogue, https://www.vivc.de/index.php

[29] Gh. Savin et al., Cercetări referitoare la utilizarea soiurilor noi de viţă de vie apirene în industria alimentară, Lucrări ştiinţifice, USAMV "Ion Ionescu de la Brad" Iaşi, Seria Horticultură 48, 265 (2005) 